\title{
PENDIDIKAN KARAKTER DI SEKOLAH DASAR KECAMATAN TELUK NAGA KABUPATEN TANGERANG
}

\author{
${ }^{1}$ Nirna Nirmala, ${ }^{2}$ Herry Nuraini \& ${ }^{3}$ Marrieta Moddies Swara \\ ${ }^{1}$ Fakultas Ilmu Pendidikan dan Keguruan, Universitas Islam Syekh-Yusuf \\ Email:nnirmala@unis.ac.id
}

\begin{abstract}
Character building has been carried out in the school environment, from early childhood to higher education. This study focuses on two character education values namely religious and discipline. This study used a descriptive qualitative approach, and the purpose of this study was to identify the application of two values of character education in the subjects and school culture in elementary school in Teluk Naga District, Tangerang Regency. The number of samples in this research are five public elementary schools (SDN) in Teluk Naga District of Tangerang Regency, it includes one school of each village; SDN in Kampung Melaya Barat, Muara, Teluk Naga, Pangkalan, and Kampung Besar. Based on the research that has been conducted, the five schools have well applied religious and discipline values in learning activities and school culture. The implementation of these values can be carried out in opening, core, and closing activities during teaching and learning activities. Moreover, the implementation of religious and discipline values can also be implemented through the school culture, that is by facilitating students to do routine activities, becoming paragons of virtue, and conditioning.
\end{abstract}

Keywords: discipline value, religious value, character building, character education 


\begin{abstract}
Abstrak
Pendidikan karakter telah dilaksanakan di lingkungan sekolah, mulai dari tingkat sekolah usia dini sampai tingkat lanjutan atas, dimana pendidikan karakter ini dimasukkan dalam proses kegiatan belajar mengajar (KBM). Penelitian ini memfokuskan pada dua nilai pendidikan karakter yaitu; religius dan disiplin. Penelitian ini menggunakan pendekatan kualitatif deskriptif, dan tujuan penelitian ini untuk mengidentifikasi penerapan dua nilai pendidikan karakter dalam mata pelajaran dan budaya sekolah di sekolah dasar di Kecamatan Teluk Naga Kabupaten Tangerang. Jumlah sampel dalam penelitian ini sebanyak 5 SDN di Kecamatan Teluk Naga Kabupaten Tangerang, yaitu satu SDN di setiap desa yang meliputi SDN di Desa Kampung Melaya Barat, Muara, Teluk Naga, Pangkalan, dan Kampung Besar. Berdasarkan penelitian yang telah dilaksanakan, kelima SDN di Kecamatan Teluk Naga Kabupaten Tangerang telah menerapkan nilai religius dan disiplin dalam kegiatan pembelajaran dan budaya sekolah dengan baik. Penerapan nilai ini dapat dilaksanakan pada kegiatan pendahuluan, inti, dan penutup pada saat kegiatan belajar mengajar (KBM). Kemudian, pelaksanaan nilai religius dan disiplin dapat dilaksanakan melalui budaya sekolah, yaitu dengan memfasilitasi siswa melakukan kegiatan rutin, memberikan keteladanan, dan pengkondisian.
\end{abstract}

Kata kunci: nilai disiplin, nilai religius, pendidikan karakter 


\section{A. Pendahuluan}

Pendidikan karakter merupakan salah satu hal yang telah ditekankan pada pendidikan formal di Indonesia. Kurikulum 2013 yang kini digunakan dirancang dengan beberapa karakteristik yang salah satu diantaranya adalah mengembangkan keseimbangan antara sikap spiritual dan sosial, pengetahuan, dan keterampilan, serta menerapkannya dalam berbagai situasi di sekolah dan masyarakat. Karakteristik tersebut menunjukkan bahwa pendidikan di sekolah tidak hanya berfokus pada pengembangan aspek pengetahuan dan ketrampilan, tetapi juga mementingkan pengembangan sikap siswa. Dengan kata lain, sekolah yang sering dianggap sebagai rumah kedua siswa diharapkan mampu membantu tugas orang tua dalam menumbuhkan karakter siswa. Penerapan pendidikan karakter pada pendidikan formal ini dilaksanakan mulai dari tingkat pendidikan dasar.

Pendidikan karakter di sekolah dasar (SD) merupakan salah satu awal dari penanaman karakter, karena siswa SD masih dalam tahap perkembangan. SD di Kecamatan Teluk Naga Kabupaten Tangerang juga telah mencoba menerapkan pendidikan karakter. Dalam penerapan pendidikan karakter, semua stakeholders harus dilibatkan, mulai dari keterlibatan kepala sekolah, guru, siswa, dan seluruh warga sekolah. Pelaksanaan pendidikan karakter ini dapat dilakukan pada kegiatan pembelajaran, pengembangan budaya sekolah, maupun dalam kegiatan ekstrakurikuler.

Pendidikan karakter tersebut juga memiliki berbagai muatan nilai yang pada dasarnya melibatkan aspek pengetahuan (cognitive), perasaan (feeling), dan tindakan (action) (Suyanto, 2009). Aspek-aspek tersebut dapat diimplementasikan ke dalam semua tindakan yang dapat memengaruhi karakter siswa. Dalam Puskurbuk (2011), disebutkan beberapa nilai pendidikan karakter, tetapi penelitian ini hanya fokus pada dua aspek, yaitu nilai religius dan disiplin. Kedua nilai tersebut dianggap penting untuk dipupuk sejak dini.

Nilai religius merupakan nilai moral universal atau bersifat absolut yang harus dimiliki manusia sebagai pondasi awal 
terbentuknya karakter yang baik. Namun, saat ini terlihat banyak berita di televisi yang memberitakan tentang kenakalan remaja, praktik suap, dan sebagainya. Hal tersebut tentu saja bukan hal terpuji dan mencerminkan kurangnya pemahaman tentang agama. Oleh sebab itu, penanaman nilai religius sangat penting untuk melahirkan generasi berkarakter baik.

Nilai disiplin juga sangat penting dimiliki setiap individu. Namun, di Indonesia banyak kita jumpai ketidakdisiplinan pada masyarakat. Sebagai contoh adalah masalah disiplin waktu. Jam karet seolah telah menjadi kebiasaan pada masyarakat yang dianggap lumrah. Padahal menjadi disiplin merupakan salah satu kunci kesuksesan, karena dengan bersikap disiplin maka seseorang akan melakukan sesuatu dengan hati-hati sehingga hasil yang dicapai juga akan lebih baik.

Penelitian mengenai pelaksanaan pendidikan karakter di sekolah sudah cukup banyak dilakukan. Namun, penerapan di Kabupaten Tangerang khususnya Kecamatan Teluk Naga belum terekspos lebih dalam. Oleh karena itu, peneliti tertarik untuk mengidentifikasinya. Akan tetapi, karena keterbatasan peneliti, penelitian ini hanya akan memfokuskan pada penerapan nilai religius dan nilai disiplin, khususnya dalam kegiatan pembelajaran dan pengembangan budaya sekolah.

\section{B. Metode}

Penelitian ini dilakukan dengan menggunakan pendekatan kualitatif, yaitu deskriptif kualitatif. Deskriptif kualitatif adalah suatu prosedur penelitian menggunakan data deskriptif yang berupa katakata tertulis atau lisan dari sumber yang berhubungan dengan objek penelitian. Sugiyono (2012) menyebutkan bahwa rumusan deskriptif betujuan untuk mengeksplorasi situasi sosial yang akan diteliti secara menyeluruh.

Jenis penelitian ini tidak memberikan perlakuan pada objek yang diteliti, tetapi hanya mendeskripsikan suatu kondisi secara apa adanya. Dalam penelitian ini yang akan diteliti adalah pelaksanaan

58|Pelita - Jurnal Penelitian dan Karya Ilmiah 
pendidikan karakter di sekolah dasar. Nilai-nilai yang akan diteliti difokuskan pada nilai religius dan disiplin. Nilai-nilai tersebut akan diulas penerapannya dalam kegiatan pembelajaran dan pengembangan budaya sekolah.

Penelitian ini, khususnya proses pengambilan data di lapangan, telah dilaksanakan pada bulan September-Oktober 2017. Lokasi penelitian ini adalah di Kecamatan Teluk Naga Kabupaten Tangerang yang meliputi Desa Kampung Melayu Barat, Muara, Teluk Naga, Pangkalan, dan Kampung Besar. Data diambil di lima SDN yang meliputi SDN Kampung Melayu III, SDN Lemo I, SDN Teluk Naga I, SDN Pangkalan I, dan SDN Kampung Besar.

Teknik pengumpulan data dalam penelitian ini menggunakan triangulasi teknik, yaitu menggabungkan data dari beberapa teknik. Adapun teknik yang digunakan untuk mengumpulkan data adalah observasi, wawancara, dan dokumentasi. Teknik pengumpulan data yang digunakan oleh peneliti untuk mendapatkan fakta yang ada di lapangan secara akurat / valid dan reliable. Pada penelitian ini peneliti mendapatkan informasi dari seluruh informan atau participant yang terlibat dalam penelitian ini yaitu guru khususnya wali kelas dan siswa.

Penelitian ini merupakan penelitian deskriptif kualitatif, sehingga yang menjadi instrumen penelitian adalah peneliti itu sendiri. Hal tersebut seperti yang dikatakan Sugiyono (2010, hlm. 59) bahwa instrumen atau alat penelitian dalam penelitian kualitatif adalah peneliti itu sendiri. Peneliti harus memiliki wawasan yang baik mengenai objek yang diteliti, sehingga diperoleh data yang sesuai dengan fokus penelitian. Adapun teknik pengumpulan data dalam penelitian ini adalah observasi, wawancara, dan dokumentasi, maka peneliti memerlukan instrumen sederhana seperti pedoman observasi, pedoman wawancara, dan dokumentasi berupa foto.

Data yang telah terkumpul selanjutnya dianalisis menggunakan Model Miles and Huberman (Sugiyono, 2012), yaitu melalui tiga tahapan sebagai berikut: reduksi data, penyajian data, dan penarikan kesimpulan. 


\section{Temuan Hasil Penelitian}

Hasil penelitian di lapangan menunjukkan bahwa lima SDN di Kecamatan Teluk Naga yang menjadi sampel penelitian ini telah menerapkan pendidikan karakter khususnya nilai religius dan disiplin baik dalam kegiatan pembelajaran di kelas maupun dalam pengembangan budaya sekolah. Hasil penelitian di dapat dari observasi di lapangan, wawancara dengan guru dan siswa, dan dokumentasi yang ada di lapangan.

\section{Penerapan Nilai Religius dalam Kegiatan Pembelajaran}

Pada penerapan nilai religius dalam kegiatan pembelajaran peneliti menggunakan teknik pengumpulan data melalui observasi dan wawancara. Pada observasi, peneliti sebagai pengamat / observer. Peneliti mengamati seluruh kegiatan yang ada disekolah, dimulai dari masuk sekolah, proses pembelajaran di kelas sampai waktu selesai sekolah. Peneliti hanya mengamati partisipan yang menjadi objek dalam penelitian ini yaitu siswa kelas 1 satu orang, siswa kelas 2 satu orang, siswa kelas 3 satu orang, siswa kelas 4 satu orang, siswa kelas 5 satu orang dan siswa kelas 6 satu orang dan semua wali kelas dari setiap tingkat kelas tersebut pada setiap SDN yang terlibat dalam penelitian ini.

Pengintegrasian nilai religius tidak hanya pada mata pelajaran Pendidikan Agama, tetapi juga pada mata pelajaran yang lain seperti Bahasa Indonesia, IPA, dan sebagainya. Penerapan nilai ini dilakukan pada kegiatan pendahuluan, inti, dan penutupan. Pada kegiatan pendahuluan dapat dilakukan dengan mengucap salam ketika masuk kelas, berdoa sebelum pelajaran dimulai, sejenak membaca ayat-ayat Alqur'an, dan memberikan ceramah-ceramah singkat. Ceramah singkat tersebut bisa berupa sesuatu yang berhubungan dengan materi pelajaran.

Selanjutnya pada kegiatan inti, penerapan nilai religius yang dilakukan adalah ketika menyampaikan materi, guru menghubungkannya dengan nilai-nilai religius dan pesan-pesan moral. Penerapan nilai ini juga dilakukan pada kegiatan penutup pembelajaran. Pada kegiatan penutup, guru mengajak siswa 
mengucapkan hamdalah, bersyukur atas ilmu yang telah dipelajari dan berdoa semoga ilmu tersebut berguna.

Dari hasil pengamatan / observasi yang dilakukan di setiap sekolahan yang terlibat dalam penelitian ini menunjukkan bahwa sebagian besar sekolahan sudah menerapkan nilai-nilai religius di dalam proses pembelajaran di dalam kelas yaitu pada kegiatan awal belajar guru mengajak siswa untuk membaca doa untuk memulai kegiatan belajar, pada kegiatan inti guru mengintegrasikan topik pembahasan dengan nilai-nilai religius meskipun tidak semua sekolah menggunakan buku tematik terpadu, dan pada kegiatan penutup guru mengajak siswa berdoa untuk mengakhiri kegiatan belajar pada hari tersebut. Pada saat kegiatan di luar kelas 3 sekolah SDN di Teluk Naga sudah membiasakan siswa-siswi nya untuk melaksanakan sholat Dhuha berjamaah dan mengaji secara bersama sebelum dimulainya kegiatan belajar mengajar (KBM) di dalam kelas. Kegiatan ini dilakukan pada pukul 06.45 menit setiap hari (Senin-Sabtu).

Berdasarkan hasil pengamatan di lapangan menunjukkan bahwa sebagian besar sekolahan SDN di kecamatan Teluk Naga sudah menerapkan nilai-nilai pendidikan karakter khususnya nilai religus di dalam kegiatan belajar mengajar (KBM) baik di dalam kelas maupun diluar kelas. Pengamatan ini bertujuan untuk memberikan pengetahuan dan pengamalan akan pentingnya nilai religius dalam dunia pendidikan yang akan melahirkan insan pembeharu bangsa sebagai generasi penerus bangsa yang mempunyai akhlak mulia, cerdas dan kritis. Hal ini menunjukkan bahwa pendidikan karakter yang ada pada kurikulum 2013 sudah terimplementasikan khususnya untuk nilai religius di SDN kecamatan Teluk Naga.

Pengambilan data yang kedua dengan menggunakan instrument wawancara. Wawancara ini digunakan untuk melengkapi data terdahulu yang diambil melalui observasi. Peneliti menggunakan data ini sebagai pendukung data sebelumnya. Pada kegiatan wawancara ini peneliti sebagi pewawancara / interviewer.

Pelaksanaan nilai religius dapat diintegrasikan pada kegiatan pembelajaran setiap mata pelajaran. Dengan kata lain, tidak hanya guru 
Agama saja yang bisa berperan aktif menumbuhkan nilai religius pada diri siswa. Nilai religius ini dapat disisipkan dalam semua mata pelajaran. Sebelum menerapkannya di kelas, guru juga mencantumkannya pada silabus dan RPP.

Dari hasil wawancara kepada 30 guru, sebagian besar guru-guru tersebut menyatakan bahwa nilai-nilai pendidikan karakter tercantum dalam silabus dan RPP. Hal ini juga sesuai dengan yang tercantum dalam RPP dimana tertulis nilai-nilai pendidikan karakter. Namun, dua orang guru menyatakan bahwa nilai religius tersebut hanya ada pada mata pelajaran Penididikan Agama. Hal ini mungkin dikarenakan kurangnya pemahaman guru tersebut mengenai pengintegrasian nilai pendidikan karakter dalam mata pelajaran.

Ketika mendapat pertanyaan bagaimana cara menyisipkan nilai religius dalam pembelajaran, hampir semua guru menjawab berdoa sebelum pelajaran dimulai. Hal ini menunjukkan bahwa nilai religius telah diterapkan pada kegiatan pendahuluan dalam pembelajaran. Pernyataan ini juga sesuai dengan observasi yang telah dilakukan di beberapa kelas. Selain itu, beberapa guru juga mengajak siswa untuk sejenak membaca ayat-ayat Alqur'an. Kemudian, beberapa guru juga menyatakan salah satu caranya adalah dengan memberikan sedikit ceramah keagamaan pada saat jam pelajaran.

"Biasanya saya menyisipkan nilai religius dalam pembelajaran melalui memberikan pidato pendek sebagai motivasi siswa dan juga biasanya sebelum belajar kita memulai dengan membaca doa." (G4, Oktober 2017)

"Sebelum belajar biasanya saya tadarusan bersama siswa dikelas. Selain itu, biasanya saya selalu menyisipkan beberapa pidato pendek ntuk menasehati siswa." (G6, Oktober 2017)

Adanya nilai religius dalam diri seseorang juga dapat dilihat dari tingkah laku yang dilakukan. Hal ini nampaknya diyakini oleh G10 yang menyatakan bahwa caranya menyisipkan nilai religius adalah dalam hal tutur kata yang baik serta tingkah laku pada saat pembelajaran berlangsung (G10, Oktober 2017). G17 juga meberikan contoh kecil dalam penerapan nilai religius yaitu dengan mengucap 
salam ketika masuk kelas. Beliau menyatakan, "Carannya kita mengucapkan salam ketika masuk kelas sehingga siswa bisa mengikuti hal tersebut. Itu contoh kecilnya." (G17, Oktober 2017)

Dari hasil wawancara / interview yang dilakukan di setiap sekolahan yang terlibat dalam penelitian ini menunjukkan bahwa sebagian besar sekolahan sudah menerapkan nilai-nilai religius di dalam proses pembelajaran di dalam kelas yaitu pada kegiatan awal belajar guru mengajak siswa untuk membaca doa untuk memulai kegiatan belajar, pada kegiatan inti guru mengintegrasikan topik pembahasan dengan nilai-nilai religius meskipun tidak semua sekolah menggunakan buku tematik terpadu, dan pada kegiatan penutup guru mengajak siswa berdoa untuk mengakhiri kegiatan belajar pada hari tersebut. Pada saat kegiatan di luar kelas 3 sekolah SDN di Teluk Naga sudah membiasakan siswa-siswi nya untuk melaksanakan sholat Dhuha berjamaah dan mengaji secara bersama sebelum dimulainya kegiatan belajar mengajar (KBM) di dalam kelas. Kegiatan ini dilakukan pada pukul 06.45 menit setiap hari (Senin-Sabtu).

Berdasarkan hasil interview di lapangan menunjukkan bahwa sebagian besar sekolahan SDN di kecamatan Teluk Naga sudah menerapkan nilai-nilai pendidikan karakter khususnya nilai religus di dalam kegiatan belajar mengajar (KBM) baik di dalam kelas maupun diluar kelas. Pengamatan ini bertujuan untuk memberikan pengetahuan dan pengamalan akan pentingnya nilai religius dalam dunia pendidikan yang akan melahirkan insan pembeharu bangsa sebagai generasi penerus bangsa yang mempunyai akhlak mulia, cerdas dan kritis. Hal ini menunjukkan bahwa pendidikan karakter yang ada pada kurikulum 2013 sudah terimplementasikan khususnya untuk nilai religius di SDN kecamatan Teluk Naga.

\section{Penerapan Nilai Religius dalam Budaya Sekolah}

Budaya sekolah dapat diimplementasikan dalam kegiatan rutin, keteladanan, dan pengkondisian. Peneliti telah melakukan observasi dan wawancara kepada guru dan siswa untuk menggali penerapan pendidikan karakter melalui budaya sekolah dari ketiga aspek tersebut (kegiatan rutin, keteladanan, dan pengkondisian). 
Untuk mengetahui hasil penerapan nilai religius dalam budaya sekolah, peneliti melakukan observasi. Pada kegiatan observasi ini peneliti sebagai pengamat / observer. Peneliti mengamati semua kegiatan penerapan nilai religius yang dilaksanakan oleh pihak sekolah dalam rutinitas kegiatan di sekolah baik di dalam kelas maupun diluar kelas. Hal ini bertujuan untuk mengetahui seberapa besar peranan pihak sekolah dalam mengembangkan nilai religius dalam budaya sekolah yang menjadikan nilai tersebut sebagai suatu kebiasaan. Sehingga diharapkan siswa mampu menerapkannnya dalam kehidupan nyata mereka baik di lingkungan sekolah maupun di lingkungan masyarakat.

Hasil observasi menunjukkan bahwa penerapan nilai religius melalui kegiatan rutin dapat dilakukan dengan beberapa cara antara lain, berdoa sebelum pelajaran dimulai dan diakhiri. Kegiatan ini juga seperti yang telah diulas pada penerapan nilai religius melalui pembelajaran, dimana berdoa dilakukan pada kegiatan pendahuluan dan penutupan pembelajaran. Yang kedua adalah mengucapkan salam apabila bertemu guru, tenaga pendidik, dan teman. Namun, kebiasaan mengucapkan salam ini lebih banyak dijumpai ketika siswa bertemu dengan guru. Ketika bertemu teman, mereka hanya sekedar memanggil nama atau menyapa saja. Hal ini juga seperti yang dikatakan beberapa siswa dalam wawancara.

Bentuk penerapan ketiga yaitu adanya kegiatan shalat berjamaah yang terjadwal. Kegiatan ini tentu saja membutuhkan sarana dan prasarana yang memadai. Sekolah tentu saja seharusnya menyediakan ruang ibadah yang nyaman. Namun, dari lima sekolah, hanya dua sekolah yang telah menyediakan ruang ibadah dan alat shalat yang nyaman. Namun, ada sebuah sekolah yang kebetulan berada tepat di depan masjid, sehingga kegiatan shalat berjamaah dapat dilakukan di masjid tersebut. Kemudian untuk sekolah yang lain, shalat berjamaah dilakukan di lapangan.

Kegiatan baca tulis Al-Quran juga telah menjadi kegiatan rutin di lima sekolah objek penelitian ini. Hal ini juga sesuai dengan wawancara yang dilakukan pada guru dan siswa. Observasi juga menunjukkan

$64 \mid$ Pelita - Jurnal Penelitian dan Karya Ilmiah 
bahwa guru memberikan keteladanan dengan ikut berperan aktif dalam kegiatan baca tulis Al-Quran. Disamping itu, hasil observasi juga menunjukkan bahwa dari lima sekolah, 4 diantaranya melakukan kegiatan infaq setiap Jumat dan diiringi keteladanan guru yang ikut berinfaq.

Kegiatan rutin dan keteladanan tersebut juga dapat ditunjang oleh pengkondisian. Salah satu bentuknya adalah dengan memajang tulisan yang berkaitan dengan agama. Dari lima sekolah, terlihat hanya satu sekolah yang belum melakukan pengkondisian ini. Nilai religius juga dapat tercermin dari sikap toleransi antar pemeluk agama. Di sebuah sekolah, hal ini dapat ditunjukkan salah satunya dengan menyediakan ruangan khusus untuk poelaksanaan pelajaran agama lain. Observasi menunjukkan hanya satu sekolah saja yang telah menyediakan ruangan khusus. Menurut beberapa siswa, ketika pelajaran agama berlangsung, siswa non muslim ikut dan diam saja di kelas.

Setelah melakukan observasi pada guru dan siswa, dapat disimpulkan bahwa sebagian besar sekolahan SD yang ada di kecamatan Teluk Naga sudah menerapkan nilai religius dalam budaya sekolah. Kelima sekolahan tersebut telah menerapkan nilai religius melalui budaya sekolah yang diimplementasikan dalam kegiatan rutin, keteladanan, dan pengkondisian. Ketiga bentuk tersebut saling melengkapi, sebagai contoh, kegiatan shalat berjamaah dapat berlangsung dengan baik dengan adanya keteladanan dari guru dan perlu adanya pengkondisian sarana dan prasarana untuk dapat berlangsungnya kegiatan tersebut meskipun ada satu sekolahan yang belum memiliki sarana dan prasarana beribadah yang memadai.

Dari hasil observasi menunjukkan bahwa sebagian besar sekolahan SD yang ada di kecamatan Teluk Naga khususnya 5 SDN yang terlibat dalam object penelitian ini sudah menerapkan nilai religius dalam budaya sekolah. Dengan adanya nilai religius diharapkan siswa mempunyai karakter yang bagus atau mulia dalam mengamalkan nilai religius dalam kehidupan sehari-hari baik di sekolah maupun di masyarakat. 
Selain dari observasi, peneliti juga melakukan kegiatan interview sebagai salah satu teknik pengumpulan data yang digunakan sebagai pendukung data terdahulu. Pada kegiatan interview, peneliti sebagai pewawancara / interviewer. Wawancara ini dilakukan kepada guru dan siswa yang terlibat dalam pnelitian ini dengan menggunakan pedoman wawancara unstructured. Maksudnya pertanyaan yang di ajukan peneliti tidak berpatokan kepada guidelines. Pertanyaan bisa berkembang sesuai situasi dan kondisi yang ada dilapangan.

Adanya nilai religius dalam diri seseorang juga dapat dilihat dari tingkah laku yang dilakukan. Hal ini nampaknya diyakini oleh G10 yang menyatakan bahwa caranya menyisipkan nilai religius adalah dalam hal tutur kata yang baik serta tingkah laku pada saat pembelajaran berlangsung (G10, Oktober 2017). G17 juga meberikan contoh kecil dalam penerapan nilai religius yaitu dengan mengucap salam ketika masuk kelas. Beliau menyatakan, "Carannya kita mengucapkan salam ketika masuk kelas sehingga siswa bisa mengikuti hal tersebut. Itu contoh kecilnya." (G17, Oktober 2017)

Hal ini didukung oleh pernyataan siswa pada saat diwawancarai yang menyatakan adanya penerapan nilai religius dalam budaya sekolah. Berikut adalah beberapa kutipan hasil wawancara peneliti kepada siswa. S10 menyatakan bahwa "setiap masuk kelas ya kami pasti memberi salam" (S10, Oktober 2017). S17 menyatakan "Kalau ketemu guru di luar sekolah kita harus menyapa atau memberi salam" (S17, Oktober 2017). S12 menyatakan "kita juga harus menghormati teman yang beragama lain" (S12, Oktober 2017).

Dari hasil wawancara ini menunjukkan bahwa semua participant dari guru dan siswa yang terlibat dalam penelitian ini menyatakan bahwa nilai religius sudah diterapkan di dalam budaya sekolah. Hal ini berarti sebagian besar sekolahan SD yang ada di kecamatan Teluk Naga sudah menerapkan nilai religius dalam budaya sekolah. Penerapan nilai religius tidak hanya diterapkan di dalam proses pembelajaran saja melainkan sudah merupakan suatu kebiasaan atau rutinitas yang ada di sekolahan sehingga menjadi sebuah budaya sekolah yang positif.

66|Pelita - Jurnal Penelitian dan Karya Ilmiah 


\section{Penerapan Nilai Disiplin dalam Kegiatan Pembelajaran}

Penerapan nilai disiplin dalam pembelajaran di lima sekolah juga telah dilaksanakan dengan cukup baik. Hal ini dapat dilihat dari hasil observasi dan wawancara yang dilakukan peneliti. Peneliti sebagai pengamat (observer) melakukan pengamatan terhadap penerapan nilai disiplin dalam kegiatan pembelajaran. Kegiatan ini dilakukan untuk mengetahui peranan nilai disiplin dalam pembentukkan karakter siswa dalam proses pembelajaran / kegiatan belajar mengajar (KBM) di lingkungan sekolah.

Dari hasil pengamatan yang dilakukan oleh peneliti menunjukan bahwa sebagian besar sekolahan yang ada di kecamatan Teluk Naga sudah menerapkan nilai disiplin dalam kegiatan pembelajaran di dalam kelas maupun di luar kelas. Ini berarti sebagian besar sekolahan SD sudah menerapkan nilai disiplin dalam proses pembelajaran meskipun ada beberapa siswa yang belum tepat waktu dalam mengumpulkan tugas pekerjaan rumah (PR) dan masih ada beberapa siswa yang datang terlambat. Tapi untuk nilai disiplin yang lainnya sudah terimplementasikan dengan baik selaras dengan tujuan dari kurikulum 2013.

Guru-guru yang diwawancara juga menyatakan bahwa mereka telah menerapkan nilai disiplin dalam pembelajaran. Mereka juga mengatakan bahwa nilai disiplin tersebut tercantum dalam silabus dan RPP. Kemudian, G16 (Oktober 2017) menyatakan bahwa salah satu cara membentuk disiplin siswa pada saat KBM berlangsung adalah disiplin dalam belajar dengan tidak bercanda di kelas. G17 (Oktober 2017) menambahkan, penerapan disiplin contohnya PR harus dikumpulkan tepat waktu, dan saat guru menjelaskan siswa dihimbau untuk tenang dan konsentrasi.

Adanya peraturan juga merupakan salah satu usaha untuk menumbuhkan disiplin siswa, seperti yang dikatakan G2 (Oktober 2017) bahwa cara menumbuhkan disiplin dengan menerapkan peraturan di kelas. Selain itu, kegiatan berbaris sebelum kelas juga dianggap hal yang menumbuhkan disiplin. Dalam kegiatan berbaris juga bisa sekaligus dilakukan pemeriksaan kerapihan siswa. 
Berdasarkan hasil interview atau wawancara menunjukkan bahwa semua participant menyatakan pentingnya penerapan nilai disiplin di dalam proses pembelajaran. Ini berarti bahwa sebagian besar participant menyatakan pentingnya menerapkan nilai disiplin di sekolah. Sehingga diharapkan siswa mampu melaksanakan semua tugas dengan tepat waktu dan mematuhi peraturan yang berlaku baik dilingkungan sekolah, keluarga maupun masyarakat.

\section{Penerapan Nilai Disiplin dalam Budaya Sekolah}

Sekolah memiliki peran yang cukup penting dalam membina disiplin siswa. Adanya peraturan sekolah diyakini sebagai salah satu cara untuk menumbuhkan disiplin siswa. Observasi dilaksanakan untuk mengetahui seberapa besar penerapan nilai disiplin dalam budaya sekolah yang dapat berimbas langsung baik terhadap guru maupun siswa dan warga sekolah yang lainnya. Pada kegiatan ini peneliti mengamati semua kegiatan participant yang terlibat pada saat jam diluar kelas seperti kegiatan pada saat sebelum masuk kelas, jam istirahat, dan jam pulang.

Dari hasil pengamatan ditemukan bahwa bagi siswa dan guru yang datang terlambat pada saat upacara bendera setiap hari Senin tidak diperkenankan untuk memasuki gerbang sekolah sampai upacara selesai. Bagi siswa yang melanggar peraturan akan mendapatkan sanksi seperti surat peringatan atau teguran secara lisan. Sedangkan bagi para guru yang melanggar peraturan juga akan mendapatkan sanksi serupa yaitu teguran secra lisan/tertulis dan suratan peringatan ataupun dirumahkan secara tidak hormat apabila melanggar peraturan yang berat.

Observasi penerapan nilai disiplin melalui budaya sekolah juga telah dilakukan peneliti. Observasi tersebut dilihat dari tiga aspek, yaitu kegiatan rutin, keteladanan, dan pengkondisian. Observasi menunjukkan bahwa kelima sekolah dasar yang menjadi objek penelitian ini telah menerapkan nilai disiplin sesuai dengan indikator yang telah disusun peneliti.

68|Pelita - Jurnal Penelitian dan Karya Ilmiah 
Berdasarkan hasil penelitian di lapangan, sebagian besar sekolahan SD yang ada di kecamatan Teluk Naga menerapkan nilai disiplin dalam budaya sekolah. Hal ini berarti mennunjukkan bahwa sebagian besar sekolahan SD yang ada di kecamatan Teluk Naga sudah menerapkan nilai disiplin dalam budaya sekolah meskipun ada satu sekolahan yang kurang menerapkan nilai disiplin seperti tidak dikuncinya pagar sekolah pada jam-jam pembelajaran. Namun untuk nilai disiplin yang lainnya sudah diimplementasikan secara langsung dan nyata dalam kegiatan budaya sekolah.

Dalam menerapkan peraturan sekolahan pun harus tegas, dan perlu adanya sanksi bagi yang melanggar. Hal ini sejalan dengan pendapat G11 (Oktober 2017) yang menyatakan bahwa sekolah sebaiknya mdiasenerapkan tata tertib yang tegas. G8 dan G9 (Oktober 2017) menambahkan bahwa perlu adanya sanksi yang mendidik bagi yang melanggar tata tertib sekolah. Disamping itu, kegiatan lainnya yang dapat memupuk disiplin siswa adalah upacara, dan beberapa guru pun menganggap kegiatan upacara sebagai salah satu upaya menanamkan disiplin.

Dalam kegiatan rutin dapat dilihat bahwa kelima SDN telah melakukan semua indikator yang digunakan peneliti. Observasi menunjukkan siswa di sekolah-sekolah tersebut telah terbiasa datang ke sekolah sesuai dengan waktu yang telah ditentukan. Selain itu, siswa mengenakan seragam sesuai dengan ketentuan. Namun, untuk siswi yang memakai kerudung belum ada keseragaman. Hal ini seperti yang diungkapkan oleh salah satu guru di SDN 3, "Tetapi untuk kerudung dibebaskan, karena sekolah kami tidak melulu Islam." Disamping itu, tampak juga bahwa siswa berusaha untuk mematuhi peraturan sekolah dengan sebaik-baiknya.

Menurut hasil wawancara, kegiatan rutin lainnya yang dilakukan untuk menumbuhkan disiplin adalah dengan mengadakan upacara hari Senin. Selain itu, kegiatan berbaris sebelum masuk kelas juga menjadi salah satu kegiaan rutin di sekolah-sekolah tersebut. Dalam kegiatan berbaris ini juga dapat dilakukan pemeriksaan kelengkapan dan kerapihan siswa yang juga bisa meningkatkan kedisiplinan. 
Selain kegiatan rutin siswa, penerapan disiplin juga perlu dukungan guru dalam bentuk keteladanan, sebagai contoh adalah guru harus datang tepat waktu dan mengenakan pakaian yang sesuai ketentuan. Dari tabel 4.2 dapat dilihat bahwa bentuk keteladanan tersebut telah dilakukan. Namun, dalam wawancara dengan siswa, ada beberapa siswa yang menyatakan bahwa ada guru yang datang terlambat. Akan tetapi keterlambatan guru tersebut tidak dapat dianggap sebagai kebiasaan, karena sebagian besar guru telah datang tepat waktu. Kesadaran guru-guru akan pentingnya tepat waktu juga nampak dari beberapa hasil wawancara.Penerapan melalui budaya sekolah yang ketiga yaitu melalui pengkondisian. Bentuk pengkondisian ini contohnya adalah dengan menutup gerbang sekolah saat bel masuk berbunyi.

Bentuk pengkondisian ini seperti pendapat dari G19 (Oktober 2017), "Pengkondisian ini contohnya adanya gerbang yang apabila bel berbunyi gerbang akan ditutup." Kemudian, observasi menunjukkan bahwa dari lima SDN, hanya satu sekolah yang tidak melakukannya dan untuk SDN 3 saat observasi dilakukan sedang ada perbaikan pintu gerbang sehingga tidak ditutup. Namun, S4 dan S6 menyatakan bahwa gerbang sekolah ditutup hanya pada saat upacara saja. Beberapa siswa juga menyatakan bahwa gerbang sekolah kadang-kadang ditutup dan kadang-kadang tidak. Dapat disimpulkan bahwa kegiatan menutup gerbang sekolah belum terlaksana dengan tegas.

Pengkondisian yang lain adalah adanya peraturan sekolah yang tegas, dan dapat dilihat bahwa kelima sekolah telah memiliki peraturan sekolah yang jelas. Sejalan dengan ini, G3 (Oktober 2017) menyatakan bahwa bentuk pengkondisian sekolah adalah dengan membuat peraturan dan mengaplikasikannya dengan baik. Hasil wawancara siswa pun menunjukkan bahwa di lima sekolah tersebut peraturan sekolah telah benar-benar dilaksanakan. Menurut G6 (Oktober 2017, "Tujuan membuat peraturan adalah agar menjadikan siswa tertib dan disiplin." Selain itu, bentuk pengkondisian yang dilakukan adalah sekolah memaksa siswa untuk disiplin tapi dengan cara-cara yang

70|Pelita - Jurnal Penelitian dan Karya Ilmiah 
menyenangkan atau tidak kasar (G17, Oktober 2017). Adanya peraturan tersebut, maka ada sanksi pula bagi pelanggarnya.

Bentuk pengkondisian yang lain menurut G7 (Oktober 2017) adalah dengan menyediakan tempat sampah. Hal ini memiliki maksud supaya siswa disiplin untuk membuang sampah pada tempatnya. Beberapa guru lain juga menyatakan hal yang sama untuk mengkondisikan disiplin siswa, yaitu dengan menyediakan tempat sampah (G9, G11, dan G20, Oktober 2017). Selain itu, memasang slogan-slogan, papan tata tertib, dan sebagainya juga dianggap sebagai bentuk pengkondisian terbentuknya disiplin siswa, seperti yang dikatakan beberapa guru (G8, G9, dan G11, Oktober 2017).

Berdasarkan hasil wawancara yang sudah dilakukan oleh peneliti menunjukkan bahwa sebagian besar SDN yang ada di kecamatan Teluk Naga sudah menerapkan nilai disiplin dalam budaya sekolah. Hal ini berarti sebagian besar sekolahan SD di kecamatan Teluk Naga sudah menerapkan nilai disiplin kepada siswa baik di dalam kelas maupun di luar kelas. Sehingga nilai disiplin yang dibentuk di sekolah menjadikan suatu kebiasaan dalam proses kegiatan belajar mengajar (KBM). Ini sesuai dengan harapan pemerintah dalam mewujudkan pendidikan karakter sejak usia dini.

\section{Kesimpulan}

Berdasarkan hasil penelitian melalui observasi dan interview yang telah dilaksanakan di Kecamatan Teluk Naga, dapat disimpulkan bahwa lima sekolah dasar yang menjadi objek penelitian ini telah melaksanakan atau menerapkan pendidikan karakter khususnya nilai religius dan nilai displin yang diintegrasikan dalam pembelajaran dan pengembangan budaya sekolah. Peneliti menyimpulkan hasil penelitian berdasarkan tujuan penelitian ini, sebagai berikut:

1. Nilai religius dan nilai disiplin dapat diterapkan pada aspek pembelajaran untuk semua mata pelajaran. Penerapan nilai ini dapat dilaksanakan pada kegiatan pendahuluan, inti, dan penutup pada saat kegiatan belajar mengajar (KBM). 
2. Nilai religius dan disiplin siswa juga dapat dilaksanakan melalui budaya sekolah, yaitu dengan memfasilitasi siswa melakukan kegiatan rutin, memberikan keteladanan, dan pengkondisian.

\section{Referensi}

Ahmadi, A. \& Uhbiyati, N. (2003). Ilmu pendidikan. Jakarta: PT Rineka Cipta.

Doni, K. (2007). Pendidikan karakter. Jakarta: Gramedia Grasindo.

Kertajaya. (2010) Pendidikan karakter. Jakarta: Gramedia.

Murniyetti, Engkizar, dan Fuady Anwar. (2016). Pola pelaksanaan pendidikan karakter terhadap siswa Sekolah Dasar. Jurnal Pendidikan Karakter.

https://www.neliti.com/id/publications/123035/polapelaksanaan-pendidikan-karakter-terhadap-siswa-sekolah-dasar (Diakses pada 12 Desember 2017, pukul 19.00)

Pusat Kurikulum dan Perbukuan (Puskurbuk). (2011). Pedoman pelaksanaan pendidikan karakter. Jakarta: Badan Penelitian dan Pengembangan Kementrian Pendidikan Nasional.

Ridwan, Muhamad. (2012). Menyemai benih karakter anak. Dari http://www.adzzikro.com

Sugiyono. (2012). Metode penelitian pendidikan (Pendekatan kuantitatif, kualitatif, dan RED). Bandung: Alfabeta.

Suyanto. (2009). Urgensi pendidikan karakter. Direkjenmanpendasmen.

Tanshzil, Sri Wahyuni. (2012). Model pembinaan pendidikan karakter pada lingkungan pondok pesantren dalam membangun kemandirian dan disiplin santri. Jurnal Penelitian Pendidikan, Vol 12 No. 2, Oktober 2012. http://jurnal.upi.edu/penelitianpendidikan/view (Diakses pada 2 Mei 2017, pukul 10.00) 
Undang-Undang Nomor 20 Tahun 2003 tentang Sistem Pendidikan Nasional.

Wibowo, Agus. (2012). Pendidikan karakter: Strategi membangun karakter bangsa berperadaban. Yogyakarta: Pustaka Pelajar.

Zulnuraini. (2012). Pendidikan Karakter: Konsep, implementasi, dan pengembangannya di Sekolah Dasar di Kota Palu. Jurnal DIKDAS No. 1 Vol. 1, September 2012.

http://pgsduntad.com/wpcontent/uploads/2014/04/ Abstrak4.pdf (Diakses pada tanggal 2 Mei 2017, pukul 10.00. 